\title{
FATALISTIC VIEWS AND THE IMPACT ON COMBATING COVID-19: BANGLADESH CONTEXT
}

\author{
Saifuddin Ahmed ${ }^{1}$ (iD) Md. Zarif Rahman ${ }^{2}$ iD Mahabuba Islam Meem $^{3}$ iD \\ ${ }^{1}$ Chairman \& Associate Professor, Department of Peace and Conflict Studies, University of Dhaka, Bangladesh. \\ ${ }^{2}$ Graduate Student, Department of Peace and Conflict Studies, University of Dhaka, Bangladesh. \\ ${ }^{3}$ Graduate Student, Department of Peace and Conflict Studies, University of Dhaka, Bangladesh.
}

\section{ARTICLE INFO}

Recieved: 10 October 2021

Revised: 11 November 2021

Accepted: 13 November 2021

Keywords:

Fatalism,

Pandemic,

South Asia,

Pessimism,

Predestination,

Health

Corresponding Author:

Md. Zarif Rahman

Email: zarifrahman111@gmail.com

Copyright (C) 2021, Middle Eastern Journal of Research in Education and Social Sciences.

This work is licensed under the Creative Commons Attribution International License (CC BY 4.0).

http://creativecommons.org/licenses/ by/4.0/
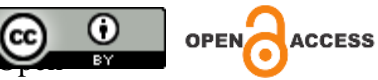

\section{ABSTRACT}

Purpose: The main objective of this study is to evaluate whether the COVID-19 pandemic has influenced the people of Bangladesh to become more fatalistic or not.

Approach/Methodology/Design: The study is of a descriptive design. The study follows a mixed-method research approach where an online survey was conducted among 406 individuals and 15 interviews of experts in different criteria have been assembled to validate the survey results properly. This survey data were analyzed based on the age and economic condition of the respondents. The in-depth interviews were collected based on six categories: Academicians, religious scholars, medical practitioners, Coronavirus-infected individuals, law enforcement officials, and journalists.

Findings: The study shows that most of the people of Bangladesh are not influenced by the fatalistic views. The COVID-19 pandemic has certainly made people more dependent on fate lately. Senior citizens of the society and people with low income are more fatalists than other groups of people in the society. Senior citizens are suffering the most from anxiety, youths of Bangladesh are facing the most uncertainty in this pandemic. None of the population groups are completely dependent on fate yet confident about the situation at the same time.

Practical Implications: The findings of this study will pave the way forward for further research in this area and help policymakers to take necessary initiatives. In short term, it will help formulating policies for the vulnerable groups. Such as, providing economic assistance for the lowest range of income group, guaranteeing old age pension for the senior citizens, access to right information, and psychological stability. In long term, this study will allow practitioners to create awareness during disasters and pandemics through expert narratives, news, and social media awareness.

Originality/value: This paper explores how the belief system of people is influenced by their socio-economic condition and how it affects their behavior in terms of combating pandemics. It also emphasizes that during disasters and pandemics, policymakers should take special initiatives for senior citizens and people with low income.

\section{INTRODUCTION}

The COVID-19 pandemic is the defining global health crisis of our time and the greatest challenge we have faced since World War Two. This pandemic is much more than a health crisis; it is also an unprecedented socio-economic crisis. Stressing people in every country, COVID-19 created devastating social, economic, and political effects that will leave deep and 
longstanding scars. Being in the corona war, policymakers worldwide are engaged in damagecontrol of the economic losses at the moment and preparing for confronting the upcoming economic crisis. In addition, there are shreds of evidence and indications that financial and banking industries around the globe might have to face remarkable instability in the forthcoming months (BRAC, 2020).

The first patient within the borders of Bangladesh was identified on March 8, 2020 and the first death from the virus was recorded on March 18 (Siddiquee \& Faruk, 2020). The government started taking measures thereafter, as a result, the government, semi-government, and a lot of the private institutions were closed off as well. Inter-district communications were pulled back to a certain degree. Returnees from across the border were home quarantined and the central authorities of the measures kept in line with the local authorities. But due to the lack of expertise and manpower, regulation of the quarantined people hasn't been possible throughout these months (Anwar, Nasrullah, \& Hosen, 2020).

The country's exports have dropped over 16\% and imports have dropped over 17\% (Siddiquee \& Faruk, 2020). Approximately 40 million students of nearly 200,000 educational institutions have fallen victims to a nationwide shutdown (BRAC, 2020). The low-income population in the beginning and a lot of the middle-income people down the road had to defy the regulatory guidelines and get back to work to make a living. This made it more difficult for the authorities to moderate the affairs of the pandemic. Due to the lack of awareness and indifference towards the guidelines, people got infected in large numbers, and eventually, a rise in the death count was observed. The Ready-Made Garments and clothing industries didn't put a hold on the production for any significant amount of time, which resulted in large numbers of people physically interacting with each other, passing the virus on to a greater degree (Siddiquee \& Faruk, 2020). Various cultural, economic, and religious factors have weighed in for having the people kept afar from preventive measures. This experience of almost a whole year seems to be gradually leading to an understandable reliance of the people onto fate. Because, at the height of the uncertainty people develop different coping mechanisms to survive within it. Fatalism can be one of the alternatives among these coping mechanisms.

Fatalistic behaviors are the outcome of the interaction between cultural factors, religious factors, and historical experiences. Fatalism has been conceptualized and operationalized in various ways. The conceptual framework of the study is derived from three fundamental variables of fatalism by Ramondt and Ramírez (2017). These are Predestination, Pessimism, and Attribution of one's health to luck.

Figure 1 - The Variables of Fatalism

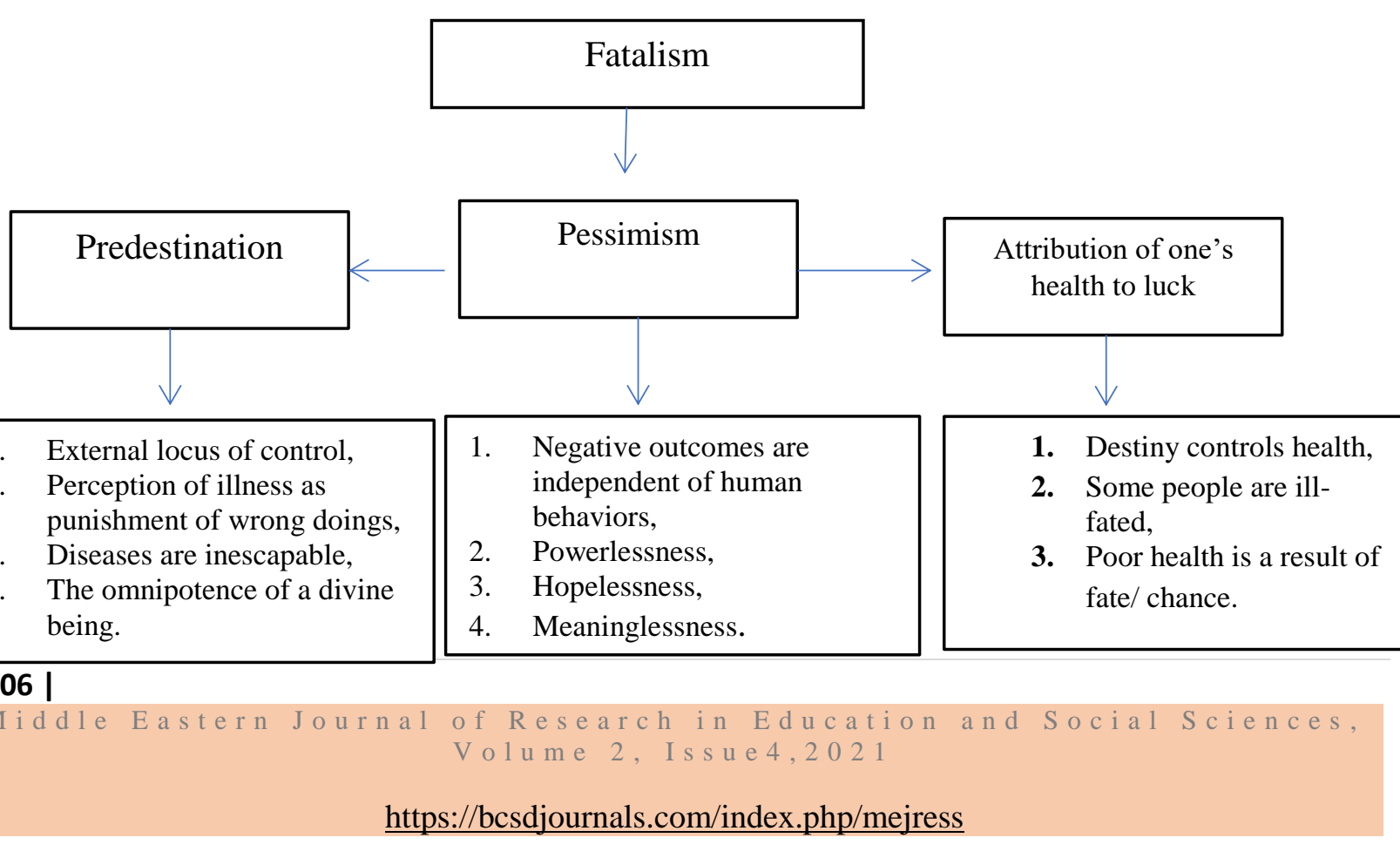


This study aims to evaluate whether the COVID-19 pandemic can turn human civilization in general and the people of Bangladesh, in particular, more fatalistic or not. Thus, the main objectives of this study are: To evaluate the perceptions of people regarding fate and Coronavirus; to examine the factors behind different behaviors of people regarding this pandemic, and to analyze the shift of perception towards fate after the pandemic. The findings of this study will pave the way forward for further research in this area and help policymakers to take necessary initiatives. In short term, it will help formulating policies for the vulnerable groups. Such as, providing economic assistance for the lowest range of income group, guaranteeing old age pension for the senior citizens, access to right information, and psychological stability. In long term, this study will allow practitioners to create awareness during disasters and pandemics through expert narratives, news, and social media awareness.

\section{LITERATURE REVIEW}

The existing pieces of literature often point out the source of fatalism as cultural, historical, or religious factors. Ruiu (2013) stresses that Fatalistic tendencies are the output of the interaction between cultural factors (and in particular of religion) and historical institutional experiences. a more regulated society tends to be also more fatalistic. At the same time, also religious beliefs and their interactions with the institutional framework seem to be an important element determining fatalistic tendencies. He argues that a more regulated society tends to be also more fatalistic. At the same time, also religious beliefs and their interactions with the institutional framework seems to be an important element determining fatalistic tendencies. Intervening into the 'clash of civilization' debate Acevedo (2008) analyzed the two principal sources of fatalism that have been pointed out in the sociological field: Cosmological and Structural fatalism. The first definition of fatalism is from Weber (1930), for which fatalism may result from distinct belief systems (laws of karma, diabolical spirits, divine predestination, stellar constellations, cycles of rebirth, and so forth) that socialize adherents to accept specific fatalistic worldviews. The second is the definition of fatalism proposed by Durkheim (1897) for which fatalism may stem from structural conditions such as inequality or extreme over-regulation.

In terms of difficult situations such as pandemics or disasters, research finds fatalism as one of the major obstacles regarding controlling the damages (see Ramnondt \& Ramirez, 2017; Hayes \& Clerk, 2020; Straughan \& Seow, 1998). Often Literatures show that fatalism significantly impacts both the preparedness of individuals to deal with announced natural disasters, i.e., fatalism obstacles the adoption of self-protecting behavior, and the ability to cope with the psychological consequence of a natural disaster, i.e., fatalism amplifies the post-traumatic stress suffered by the victims of such disasters (Perilla, Norris, \& Lavizzo,2002).

Jeronimus (2020) labels the coronavirus pandemic as a stressful life event and natural experiment where the events are connected to emotional, somatic, and mental health responses. There are many differences in personality and resilience that are seen across many regions. He further mentions that different social mitigation measures along with the economic breakdown of a country have altered our lifestyles and influenced societal values and politics. Fatalistic attitudes have a negative impact on a broad variety of health behaviors and behavioral determinants of health (Jeronimus, 2020). There is some evidence that increased exposure to media increases fatalism (Ramondt \& Ramírez, 2017). The role of fatalism also has been studied in medical literature, where it is regarded as a serious obstacle to the adoption of health screening behaviors (Straughan \& Seow,1998).

Akesson, Hayes, Hahn, Metcalfe, and Rasooly (2020) state that the belief system of individuals influences the spread of COVID-19 as it largely determines the social distancing behaviors. They present three essential findings: people vividly overestimate the infectiousness of COVID19 , providing them with correct information, however, can change their beliefs regarding the 
virus, and lastly, the more they exaggerate the infectiousness of COVID-19, the less they are willing to maintain social distancing measures. The third finding has been termed by the authors as the fatalism effect. Hayes and Clerk (2020) state that fatalistic messages to create awareness among mass people increase fatalism towards COVID-19 by making them less likely to maintain social mitigation measures. On the other hand, optimistic messages increase support for such measures. Fatalism towards the COVID-19 pandemic has a strong relation with emotional distress. This is because fatalism is positively associated with depression as a person tends to abandon efforts to engage in in-person control. The authors add that anti-fatalistic messages create a clear connection between individual actions and the spread of the virus thus making people more likely to practice social distancing measures.

Ramondt and Ramírez (2017) have shown a strong relationship between fatalism and health outcomes by marking three domains of fatalism. Predestination addresses the lack of control an individual perceives over external events. It is commonly known as the external locus of control. Diseases are considered unavoidable as they are seen as a part of the plan of God or a Divine being. Illness is often perceived as the punishment of sin or wrongdoings where a human can barely control health. Pessimism, on the other hand, comprises the set of beliefs that any kind of human behavior cannot avoid the negative consequences. It is often measured by three central elements. Powerlessness, hopelessness, and meaninglessness. Pessimism abides by the notion that death is inevitable and no matter what we do, we cannot lower our chances of getting infected regarding any disease. The last variable of fatalism is the attribution of one's health to luck. This means that health is based on luck, destiny, and fate. Since people attribute their health to fate, they see poor health as an outcome of bad luck.

Uncertainty avoidance is a useful concept to understand the fatalistic tendencies among individuals. Hofstede (2010) has defined uncertainty avoidance as the extent to which the members of a culture feel threatened by ambiguous or unknown situations. This feeling is often expressed through nervous stress and the need for predictability. It is a way of relating to the mystical forces that are perceived to control people's futures. These feelings belong to the cultural heritage of society and may lead to a collective pattern of behavior. Hofstede mentioned the prevalence of two types of uncertainty avoidance in modern societies: Weak uncertainty avoidance and Strong uncertainty avoidance. People from weak uncertainty avoidance countries show lower expressiveness and may often seem easy-going with low self-control. Their anxiety level regarding any disease is relatively low and has high scores on subjective health and wellbeing. People from strong uncertainty avoidance countries have the emotional need for rules, structure with higher stress and anxiety. Uncertainty avoidance is an important determinant in the health sector as culture is closely related to the practice of medicine in any country.

There is a significant amount of literature on fatalism and pandemics. However, there is insufficiency in research concerning the perceptions of people relating to fate with COVID-19 and the shift of perception towards fate after this pandemic.

\section{METHODOLOGY AND PROCEDURES}

This study employs the mixed method design which is the amalgamation of qualitative and quantitative approaches to collect and analyze data and information. Integrating qualitative and quantitative methods have become popular as this particular structure can provide a detailed and comprehensive framework of analysis. As the study aims to evaluate whether the COVID-19 pandemic can turn human civilization more fatalistic or not, a mixed-method research design is a good fit for this purpose. Data collection was conducted in two phases. Primary data were collected through a survey and in-depth interviews. Considering the present crisis of pandemic, an online survey was administered among 406 individuals to properly evaluate their perception regarding fate and COVID-19. This survey data was later analyzed based on the respondants' 
age and economic strata. The in-depth interviews were conducted based on six categories. These are- academicians, religious scholars, medical practitioners, Coronavirus-infected individuals, law enforcement officials, and journalists. The interview questionnaires are open-ended in nature. News and articles published in one national daily, 'The Daily Star' within the past six months were evaluated. The library research includes information gathered from internet searches such as books, journals, articles, and research papers from various websites.

\section{RESULTS AND DISCUSSION}

\section{Demographic Data of the Respondents}

\section{Demographic Information}

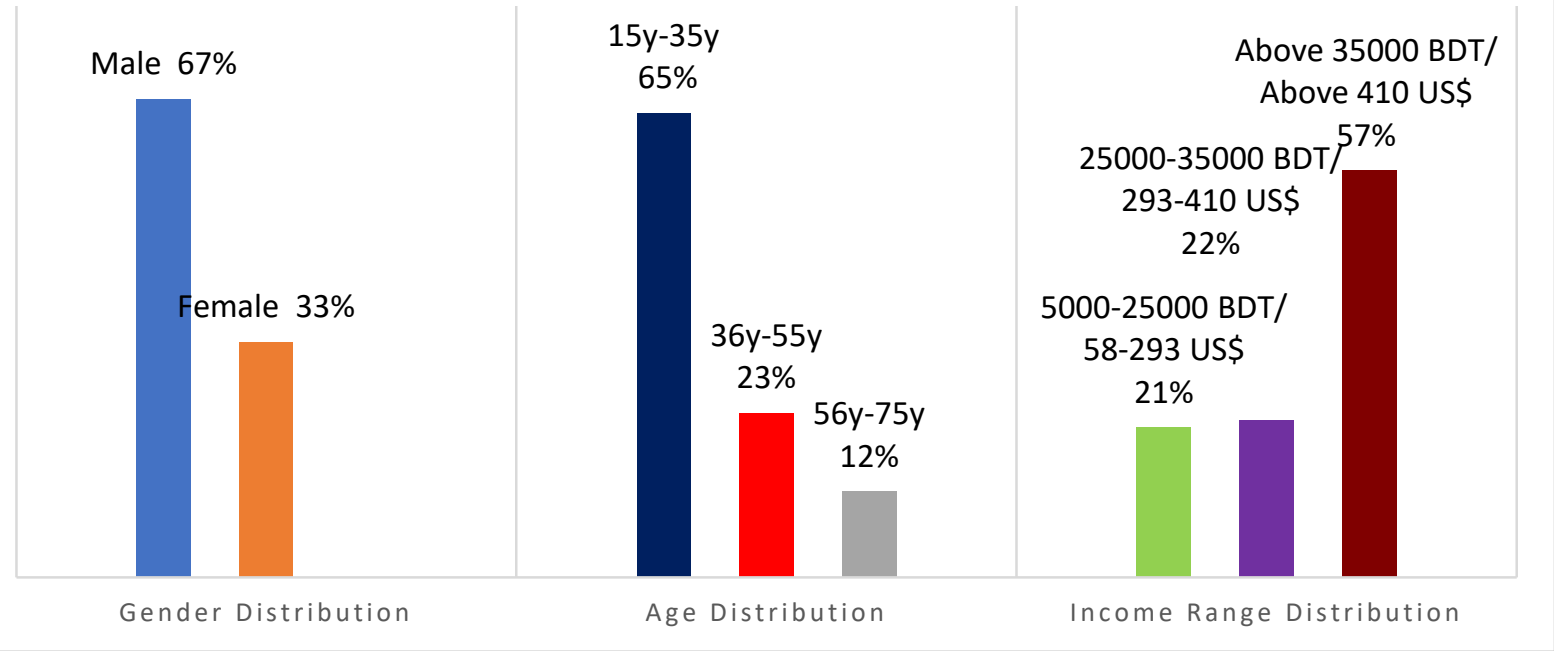

Figure 2: Demographic Information of the Respondents

The survey result shows that the category of senior citizens and people from the lowest range of income is more fatalistic than the rest of the others. The fundamental variables for the survey data analysis are the age and income of individuals. We divide their age into three categories in order to understand their perception better. The categories are youth (15-35), middle-age (36$55)$ and, senior citizens (56-above). We also divide their monthly income into three categories. They are: lowest range (5000-25000 BDT/ 58-293 US\$), middle range (25000-35000 BDT/ 293-410 US\$) and, highest range (Above $35000 \mathrm{BDT} /$ Above 410 US\$).

\section{i) Pessimism}

Based on the age structure of the individuals, the result shows that $93.75 \%$ of senior citizens think there is still a chance of getting infected with COVID-19 even after following proper hygiene rules. On the other hand, $84.03 \%$ of youths and $75.79 \%$ of middle-aged individuals think like that (See table 1). It demonstrates that senior citizens have a comparatively more pessimistic mindset.

Table 1: People Perception on chances of getting infected even after following the proper hygiene rules (Correlation between participants' age profile and responses)

\begin{tabular}{ccc} 
Age Profile & $\begin{array}{c}\text { Respondents who think that there } \\
\text { is chance of getting infected even } \\
\text { after maintaining proper hygiene } \\
\text { rules }\end{array}$ & $\begin{array}{c}\text { Respondents who do not think } \\
\text { there is chance of getting infected } \\
\text { after maintaining proper hygiene } \\
\text { rules }\end{array}$ \\
$\begin{array}{c}\text { Youth Group }(15 \mathrm{y}-35 \mathrm{y}) \\
\text { Total 263 respondents }\end{array}$ & $84.03 \%$ & $15.97 \%$ \\
\hline
\end{tabular}


Middle-Aged Group (36y -

$55 y)$ Total 95 respondents

Senior Citizen (56y - 75y)

Total 48 respondents

Based on the income profile of the individuals, the result shows that $83.53 \%$ of people in the lowest income range think there is still a chance of getting infected with COVID-19 even after maintaining the hygiene rules properly. On the other hand, $81.32 \%$ of people in the middleincome range and $63.48 \%$ of people in the highest income range think like that (See table 2). It shows that people with comparatively lower income are more pessimistic, in other words, they are more fatalistic.

Table 2: People Perception on chances of getting infected even after following the proper hygiene rules (Correlation between participants' income profile and responses)

Income Profile
Respondents who think that there is chance of getting infected even after maintaining proper hygiene

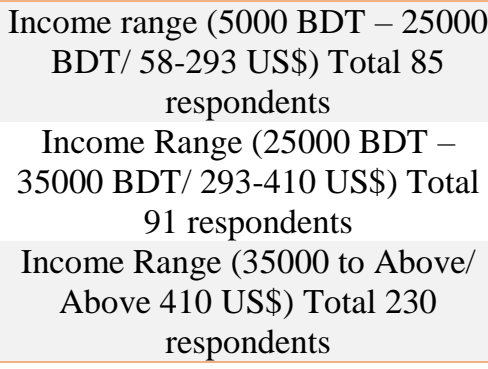
rules

Respondents who do not think there is chance of getting infected after maintaining proper hygiene rules $16.47 \%$

$83.53 \%$

$81.32 \%$ $18.68 \%$

$63.48 \%$ $36.52 \%$

Based on the age profile, all of the respondents from the senior citizen group think that strategies like lockdown and social distancing can prevent the spread of COVID-19. 91.63\% of respondents from the youth group and $96.84 \%$ respondents from the middle-age group think in the similar way. Based on the income profile, $87.06 \%$ of people in the lowest income range think lockdown and social distancing can reduce the transmission of COVID-19. But it is less than the other two income groups as $93.48 \%$ of people in the highest income range and $89.01 \%$ of people in the middle-income range think like that.

\section{ii) Predestination}

The result further shows that $91.67 \%$ of senior citizens believe that COVID-19 has been sent directly by God or a divine being. $70.72 \%$ of youths and $54.74 \%$ of middle-aged individuals think COVID-19 has been sent by God (See table 3). This kind of belief is compatible with predestination, one of the variables of fatalism.

Table 3: People's Perception on if COVID-19 has come from God (Correlation between participants' age profile and responses)

\begin{tabular}{ccc} 
Age Profile & $\begin{array}{c}\text { Respondents who believe } \\
\text { COVID-19 has come from God }\end{array}$ & $\begin{array}{c}\text { Respondents who do not believe } \\
\text { COVID-19 has come from God }\end{array}$ \\
\hline $\begin{array}{c}\text { Youth Group (15y -35y) Total 263 } \\
\text { respondents }\end{array}$ & $70.72 \%$ & $29.28 \%$ \\
$\begin{array}{c}\text { Middle-Aged Group (36y }-55 y) \\
\text { Total 95 respondents }\end{array}$ & $54.74 \%$ & $45.26 \%$ \\
$\begin{array}{c}\text { Senior Citizen (56y }-75 y) \text { Total } \\
48 \text { respondents }\end{array}$ & $91.67 \%$ & $8.33 \%$
\end{tabular}

As mentioned in the table below, $78.82 \%$ of people in the lowest income range think that 
COVID-19 has been sent directly by God or a divine being. On the contrary, $69.23 \%$ of people in the middle-income range and $63.48 \%$ of people in the highest income range think like that (See table 4).

Table 4: People's Perception on if COVID-19 has come from God (Correlation between participants' income profile and responses)

Income Profile

Income range (5000 BDT -25000
BDT/ 58-293 US\$) Total 85
respondents

Income Range (25000 BDT -

35000 BDT/ 293-410 US\$) Total

91 respondents

Income Range (35000 to Above/

Above 410 US\$) Total 230

respondents
Respondents who believe Respondents who do not believe

COVID-19 has come from God COVID-19 has come from God $78.82 \% \quad 21.78 \%$

$69.23 \%$

$30.27 \%$

$63.48 \%$

$36.52 \%$

Based on the data presented below, $83.33 \%$ of senior citizens believe that if anyone gets infected with COVID-19 even after maintaining proper hygiene rules, then it is God's will or destiny. On the other hand, $65.78 \%$ of youths and $55.79 \%$ of middle-aged individuals think like that. This is compatible with predestination (See table 5).

Table 5: People's Perception on if getting infected even after maintaining proper hygiene rules as fate (Correlation between participants' age profile and responses)

\begin{tabular}{ccc}
\hline Age Profile & $\begin{array}{c}\text { Respondents who think that } \\
\text { getting infected even after } \\
\text { maintaining proper hygiene rules } \\
\text { is the result of fate }\end{array}$ & $\begin{array}{c}\text { Respondents who do not agree } \\
\text { that getting infected even after } \\
\text { maintaining proper hygiene rules } \\
\text { is the result of fate }\end{array}$ \\
\hline $\begin{array}{c}\text { Youth Group (15y -35y) Total 263 } \\
\text { respondents }\end{array}$ & $65.78 \%$ & $34.22 \%$ \\
$\begin{array}{c}\text { Middle-Aged Group (36y - 55y) } \\
\text { Total 95 respondents }\end{array}$ & $55.79 \%$ & $44.21 \%$ \\
$\begin{array}{c}\text { Senior Citizen (56y - 75y) Total } \\
48 \text { respondents }\end{array}$ & $83.33 \%$ & $16.67 \%$ \\
\end{tabular}

On the other hand, $71.76 \%$ of people in the lowest income range believe that if anyone gets infected with COVID-19 even after maintaining proper hygiene rules, then it is God's will or destiny. Furthermore, $63.74 \%$ of people in the middle-income range and $61.30 \%$ of people in the highest income range believe the same (See table 6).

Table 6: People's Perception on if getting infected even after maintaining proper hygiene rules as fate (Correlation between participants' income profile and responses)

\begin{tabular}{ccc}
\hline Income Profile & $\begin{array}{c}\text { Respondents who think that } \\
\text { getting infected even after } \\
\text { maintaining proper hygiene rules } \\
\text { is the result of fate }\end{array}$ & $\begin{array}{c}\text { Respondents who do not agree } \\
\text { that getting infected even after } \\
\text { maintaining proper hygiene rules } \\
\text { is the result of fate }\end{array}$ \\
$\begin{array}{c}\text { Income range (5000 BDT - 25000 } \\
\text { BDT/58-293 US\$) Total 85 } \\
\text { respondents }\end{array}$ & $\begin{array}{c}71.76 \% \\
28.24 \%\end{array}$ \\
$\begin{array}{c}\text { Income Range (25000 BDT - } \\
\text { 35000 BDT/ 293-410 US\$) Total } \\
\text { 91 respondents }\end{array}$ & $63.74 \%$ & $36.26 \%$ \\
$\begin{array}{c}\text { Income Range (35000 to Above) } \\
\text { Total 230 respondents }\end{array}$ & $61.30 \%$ & $38.70 \%$ \\
\hline
\end{tabular}


As shown in the table below, $68.75 \%$ of senior citizens think that COVID-19 has appeared as a punishment from God because of the sins and ill doings. Only $37.64 \%$ of youths and $26.32 \%$ of middle-aged individuals think of it as a punishment (See table 7). This kind of belief is also closely related to predestination.

Table 7: People's Perception on COVID-19 as punishment of wrongdoings (Correlation between participants' age profile and responses)

\begin{tabular}{ccc}
\hline Age Profile & $\begin{array}{c}\text { Respondents who believe } \\
\text { COVID-19 is a punishment of } \\
\text { wrongdoing }\end{array}$ & $\begin{array}{c}\text { Respondents who do not believe } \\
\text { COVID-19 is a punishment of } \\
\text { wrongdoing }\end{array}$ \\
\hline $\begin{array}{c}\text { Youth Group (15y -35y) Total 263 } \\
\text { respondents }\end{array}$ & $37.64 \%$ & $62.36 \%$ \\
$\begin{array}{c}\text { Middle-Aged Group (36y - 55y) } \\
\text { Total 95 respondents }\end{array}$ & $26.32 \%$ & $73.68 \%$ \\
$\begin{array}{c}\text { Senior Citizen (56y - 75) Total 48 } \\
\text { respondents }\end{array}$ & $68.75 \%$ & $31.25 \%$ \\
\hline
\end{tabular}

Almost half of the lowest income range people, $49.47 \%$ believe that COVID-19 has appeared as a punishment from God because of the sins and ill doings. On the other hand, $32.97 \%$ of people in the middle-income range and $33.04 \%$ of people in the highest income range think like that (See table 8).

Table 8: People's Perception on COVID-19 as punishment of wrongdoings (correlation between participants' income profile and responses)

\begin{tabular}{ccc}
\hline Income Profile & $\begin{array}{c}\text { participants' income profile and responses) } \\
\text { Respondents who believe } \\
\text { COVID-19 is a punishment of } \\
\text { wrongdoing }\end{array}$ & $\begin{array}{c}\text { Respondents who believe } \\
\text { COVID-19 is a punishment of } \\
\text { wrongdoing }\end{array}$ \\
\hline $\begin{array}{c}\text { Income range (5000 BDT - 25000 } \\
\text { BDT/ 58-293 US\$) Total 85 } \\
\text { respondents }\end{array}$ & $49.41 \%$ & $50.59 \%$ \\
$\begin{array}{c}\text { Income Range (25000 BDT - } \\
35000 \text { BDT/ 293-410 US\$) } \\
\text { Total 91 respondents }\end{array}$ & $32.97 \%$ & $67.03 \%$ \\
$\begin{array}{c}\text { Income Range (35000 to Above/ } \\
\text { Above 410 US\$) Total 230 } \\
\text { respondents }\end{array}$ & $33.04 \%$ & $66.96 \%$ \\
\end{tabular}

While most of the survey respondents think social factors are the main reasons why COVID-19 has widespread transmission in this society, $4.17 \%$ of senior citizens, $3.42 \%$ of youths, and $3.16 \%$ of middle-aged individuals think religious factors are more responsible. Religion, in terms of fatalism, is closely related to predestination. Based on the income profile, $3.53 \%$ of people in the lowest income range think religious factors are the main reason behind the widespread transmission of COVID-19 in society. On the other hand, $2.20 \%$ of people in the middle-income range and $3.48 \%$ of people in the highest income range think like that.

In the same way, $27.08 \%$ of senior citizens believe religious belief is more capable of combating COVID-19. On the other hand, $4.94 \%$ of youths and $6.32 \%$ of middle-aged individuals think like that. Based on the income profile, $4.71 \%$ of people in the lowest income range think religious belief is more capable of combating COVID-19. $6.59 \%$ of people in the middleincome range and $7.83 \%$ of people of the highest income have a similar belief. This trend is quite the opposite of popular conceptions.

\section{iii) Attribution of one's health to luck}

From the experience of the COVID-19 situation, about $90.48 \%$ of senior citizens believe that 
health and diseases depend on fate. On the contrary, only $35.74 \%$ of the youth respondents and $41.05 \%$ of the middle-aged people think similarly (See table 9 ).

Table 9: People perception on whether health and diseases depend on fate from the experience of COVID-19 (Correlation between participants' age profile and responses)

\begin{tabular}{lcc}
\hline Age Profile & $\begin{array}{c}\text { Respondents who start to believe } \\
\text { health and diseases depend on fate } \\
\text { (from the experience of COVID- } \\
\text { 19) }\end{array}$ & $\begin{array}{c}\text { Respondents who still do not } \\
\text { believe health and diseases depend } \\
\text { on fate (from the experience of } \\
\text { COVID-19) }\end{array}$ \\
\hline $\begin{array}{l}\text { Youth Group (15y -35y) Total } 263 \\
\text { respondents }\end{array}$ & $35.74 \%$ & $64.26 \%$ \\
$\begin{array}{l}\text { Middle-Aged Group (36y }-55 y) \\
\text { Total 95 respondents }\end{array}$ & $41.05 \%$ & $58.95 \%$ \\
$\begin{array}{l}\text { Senior Citizen (56y }-75 y) \text { Total } \\
48 \text { respondents }\end{array}$ & $90.48 \%$ & $9.52 \%$ \\
\end{tabular}

Based on the data presented below, $45.88 \%$ of people in the lowest income range believe that an individual's health and diseases depend largely on fate. On the contrary, $43.96 \%$ of people in the middle-income range and $38.70 \%$ of people in the highest income range have a similar belief (See table 10).

Table 10: People perception on whether health and diseases depend on fate from the experience of COVID-19 (Correlation between participants' income profile and responses)

\begin{tabular}{ccc}
\hline Income Profile & $\begin{array}{c}\text { Respondents who start to believe } \\
\text { health and diseases depend on fate } \\
\text { (from the experience of COVID- } \\
\text { 19) }\end{array}$ & $\begin{array}{c}\text { Respondents who still do not } \\
\text { believe health and diseases depend } \\
\text { on fate (from the experience of } \\
\text { COVID-19) }\end{array}$ \\
\hline $\begin{array}{c}\text { Income range (5000 BDT - 25000 } \\
\text { BDT/58 US\$-293\$) Total 85 } \\
\text { respondents }\end{array}$ & $45.88 \%$ & $54.12 \%$ \\
Income Range (25000 BDT - & & \\
35000 BDT/293 US\$-410 US\$) & $43.96 \%$ & $56.04 \%$ \\
Total 91 respondents & & \\
Income Range (BDT 35000 to & $38.70 \%$ & $61.30 \%$ \\
Above/Above 410 US\$) Total 230 \\
respondents
\end{tabular}

As shown in the table below, $72.92 \%$ of senior citizens think COVID-19 has made other people more dependent on fate. On the other hand, $51.33 \%$ of youths and $41.05 \%$ of middle-aged individuals feel the same (see table 11). Furthermore, $64.58 \%$ of senior citizens think they have personally become more dependent on fate because of the virus. However, only $27.76 \%$ of youths and $21.05 \%$ of middle-aged individuals believe they have become more dependent on fate because of COVID-19.

Table 11: People's perception on whether COVID-19 has made people more dependent on fate or not (Correlation between participants' age profile and responses)

\begin{tabular}{ccc}
\hline Age Profile & $\begin{array}{c}\text { Respondents who think COVID- } \\
\text { 19 has made people more } \\
\text { dependent on fate }\end{array}$ & $\begin{array}{c}\text { Respondents who do not think } \\
\text { COVID-19 has made people more } \\
\text { dependent on fate }\end{array}$ \\
\hline $\begin{array}{c}\text { Youth Group (15y -35y) Total 263 } \\
\text { respondents }\end{array}$ & $51.33 \%$ & $48.67 \%$ \\
$\begin{array}{c}\text { Middle-Aged Group (36y }-55 y) \\
\text { Total 95 respondents }\end{array}$ & $41.05 \%$ & $58.95 \%$ \\
$\begin{array}{c}\text { Senior Citizen (56y - 75y) Total } \\
48 \text { respondents }\end{array}$ & $72.92 \%$ & $27.08 \%$ \\
\hline
\end{tabular}


Based on the data presented below, $52.94 \%$ of people in the lowest income range think COVID19 has made people more dependent on fate. Also, $52.75 \%$ of the people from the middleincome range and $46.96 \%$ of people from the highest income range think similarly (See table 12). On the other hand, $31.76 \%$ of people in the lowest income range believe they have personally become more dependent on fate because of COVID-19. 34.07\% of people from the middle-income range and $26.52 \%$ of people from the highest income range believe they have personally become more dependent on fate because of the pandemic.

Table 12: People's perception on whether COVID-19 has made people more dependent on fate or not (Correlation between participants' income profile and responses)

\begin{tabular}{ccc}
\hline Income Profile & $\begin{array}{c}\text { Respondents who think COVID- } \\
\text { 19 has made people more } \\
\text { dependent on fate }\end{array}$ & $\begin{array}{c}\text { Respondents who do not think } \\
\text { COVID-19 has made people more } \\
\text { dependent on fate }\end{array}$ \\
$\begin{array}{c}\text { Income range (5000 BDT - 25000 } \\
\text { BDT/ 58-293 US\$) Total 85 } \\
\text { respondents }\end{array}$ & $\begin{array}{c}47.94 \% \\
\text { Income Range (25000 BDT - }\end{array}$ & $47.25 \%$ \\
35000 BDT/ 293-410 US\$) Total \\
91 respondents
\end{tabular}

However, even if the senior citizens are being proved to be more fatalists or dependent on fate than the other two age categories, they are the least confident about the present situation. Based on the data presented below, $90.48 \%$ of them are suffering from anxiety in the middle of this pandemic. On the other hand, $81.05 \%$ of middle-aged individuals and $83.27 \%$ of youths are facing anxiety in this situation (See table 13).

Table 13: People's response on whether they are feeling anxious because of the COVID-19 situation or not (Correlation between participants' age profile and responses)

\begin{tabular}{c|cc}
\hline Age Profile & $\begin{array}{c}\text { Respondents who feel anxious } \\
\text { because of the COVID-19 } \\
\text { situation }\end{array}$ & $\begin{array}{c}\text { Respondents who do not feel } \\
\text { anxious because of the COVID-19 } \\
\text { situation }\end{array}$ \\
\hline $\begin{array}{c}\text { Youth Group (15y -35y) Total 263 } \\
\text { respondents }\end{array}$ & $83.27 \%$ & $16.73 \%$ \\
$\begin{array}{c}\text { Middle-Aged Group (36y - 55y) } \\
\text { Total 95 respondents } \\
\text { Senior Citizen (56y - 75y) Total } \\
48 \text { respondents }\end{array}$ & $81.05 \%$ & $18.95 \%$ \\
\hline
\end{tabular}

In terms of suffering from anxiety, people of the lowest income range and highest income range are on the same page almost with respectively $81.8 \%$ and $81.74 \%$. People of the middle-income range are slightly in a better position in this regard with $76.92 \%$ of them suffering from anxiety in this pandemic (See table 14).

Table 14: People's response on whether they are feeling anxious because of the COVID-19 situation or not (Correlation between participants' income profile and responses) Income Profile

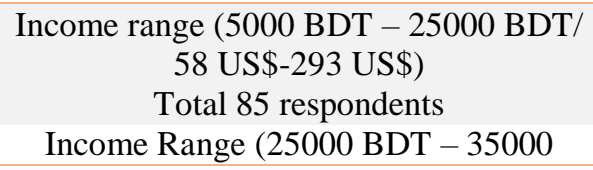

Respondents who do not feel anxious because of the COVIDanxious because of the COVID-19 situation 19 situation $18.82 \%$

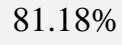

$78.92 \%$
$23.08 \%$ 
Among the three age categories, the least fatalists are the youths who are suffering from the most uncertainty in this situation comprising almost $68.06 \%$ of them. On the contrary, $57.14 \%$ of senior citizens and $45.26 \%$ of middle-aged individuals are suffering from uncertainty (See table 15).

Table 15: People's response on whether they are feeling uncertain in this pandemic situation (Correlation between participants' age profile and responses)

\begin{tabular}{ccc}
\hline Age Profile & $\begin{array}{c}\text { Respondents who feel } \\
\text { uncertain in this pandemic } \\
\text { situation }\end{array}$ & $\begin{array}{c}\text { Respondents who do not feel } \\
\text { uncertain in this pandemic } \\
\text { situation }\end{array}$ \\
\hline $\begin{array}{c}\text { Youth Group (15y -35y) Total } \\
\text { 263 respondents }\end{array}$ & $68.06 \%$ & $31.94 \%$ \\
$\begin{array}{c}\text { Middle-Aged Group (36y - } \\
\text { 55y) Total 95 respondents }\end{array}$ & $45.26 \%$ & $54.74 \%$ \\
$\begin{array}{c}\text { Senior Citizen (56y - 75y) } \\
\text { Total 48 respondents }\end{array}$ & $57.14 \%$ & $42.86 \%$ \\
\hline
\end{tabular}

Even though people from the lowest income range are proven to be more fatalist than the other two categories of people, they are the ones suffering the most from uncertainty with around $68.24 \%$ of them. On the other hand, $60.44 \%$ of people in the middle-income range and $60.87 \%$ of people in the highest income range are suffering from uncertainty (See table 16).

Table 16: People's response on whether they are feeling uncertain in this pandemic situation (Correlation between participants' income profile and responses)

\begin{tabular}{ccc}
\hline Income Profile & $\begin{array}{c}\text { Respondents who feel } \\
\text { uncertain in this } \\
\text { pandemic situation }\end{array}$ & $\begin{array}{c}\text { Respondents who do not feel } \\
\text { uncertain in this pandemic } \\
\text { situation }\end{array}$ \\
\hline $\begin{array}{c}\text { Income range (5000 BDT - 25000 BDT/ 58 } \\
\text { US\$-293 US\$) Total 85 respondents }\end{array}$ & $68.24 \%$ & $31.76 \%$ \\
$\begin{array}{c}\text { Income Range (25000 BDT - 35000 } \\
\text { BDT/293 US\$-410 US\$) Total 91 } \\
\text { respondents }\end{array}$ & $60.44 \%$ & $39.56 \%$ \\
$\begin{array}{c}\text { Income Range (BDT 35000 to Above/ } \\
\text { Above 410 US\$) Total 230 respondents }\end{array}$ & $60.87 \%$ & $39.13 \%$ \\
\hline
\end{tabular}

Most of the respondents believe that the virus can be controlled by humans. People who are dependent on fate also believe that humans can control COVID-19. However, senior citizens and people from the lowest income range have comparatively less faith in this matter. The survey data shows that, $31.25 \%$ of respondents from the senior citizen group and $25.88 \%$ of people from the lowest income range think that COVID-19 cannot be controlled by a human.

An expert during the interview says "it is true that we are at the hands of fate, but that doesn't mean we're completely helpless or do not have any number of significant roles to play" $(\mathrm{H}$. A. Rashid, personal communication, August 22, 2020). On the other hand, numerous updates regarding COVID-19 have made people more dependent on fate. Figuring out the reason behind this, another expert reveals during the interview that people have seen some big shots of the countries losing their lives to the virus. These people had enough money but could not survive. These are making people dependent on fate (A. Raian, September 6, 2020). An academic scholar also adds to this explanation in his interview saying that people automatically become 
fatalists when there is nothing they can do about a situation. They are now thinking that whatever happens will happen (B. Hossain, personal communication, September 5, 2020). However, most survey respondents are suffering from uncertainty and anxiety. One of the interviewees reveals that "we are always afraid of anything that is alien to us" (M. Obayedullah, personal communication, August 21, 2020).

One common trend has appeared from the survey results that more or less every individual believes that COVID-19 has been sent directly by God or a divine being. A medical practitioner during the interview states that "we see that patients tend to believe that their illness is a punishment from God for their wrongdoings" (A. Mamun, personal communication, August 31, 2020). Among the respondents, senior citizens not only see the virus as sent by God but also consider it as punishment. Some people also think of it as a form of test in this world. A religious scholar reveals during the interview that sickness is the result of two things, punishment from God and as a form of test in this world. God gives us punishment as a chance to re-evaluate ourselves (A. Kabir, personal communication, August 19, 2020). There are several debates on this matter. However, the majority of the respondents do not see it as a punishment from God. For example, another religious scholar thinks that the virus is not a punishment. God loves His people and He can never punish humans (Father K. Corraya, personal communication, September 14, 2020). There are still people who associate this pandemic with the specific wrongdoing of human beings. A law enforcement official says during the interview "People believe that the virus came because Muslims around the world have been the victims of many oppression" (A. Raian, September 6, 2020). This kind of belief does not only exist in Bangladesh, it can rather be observed throughout South Asia. For example, at the beginning of the pandemic, the people of India held Muslims of that country responsible for the widespread transmission of COVID-19.

In other words, religious people believe that everything comes from God. Among them, people who comparatively follow the religion more strictly, see the diseases as punishment from God. But pandemics like COVID-19 make people more fatalist. In this case, an academic scholar reveals during the interview that, even at places where natural calamities hit hard, people are more dependent on fate and a divine being. Since these are the situations they cannot control, they put their faith in a divine being who controls everything (S. A. Chowdhury, personal communication, September 1, 2020).

We can see from the results that senior citizens and people from the lowest income range are comparatively more fatalists among the respondents. In the context of Senior citizens being more, there are three core reasons involve. Firstly, most of the senior citizens are financially dependent on their family members. This financial dependency creates a sense of insecurity. Along with this insecurity, the second factor is related to their physical vulnerability as most of the senior citizens suffer from various health complications. Thirdly, the lack of information related to COVID-19 pandemic and awareness as most the senior citizens are not well connected with the sources (social media, internet, TV, Newspapers etc.). In other words, one of the reasons why senior citizens are comparatively more fatalist is that information related to awareness has not reached them properly. We can see that most respondents in the survey are youths and middle-aged individuals. Since it is an online survey, people who have access to the internet could participate more. On the other hand, a survey among senior citizens has been conducted through phone calls or physically. Since, most information related to COVID-19 is available on the internet, youths and middle-aged individuals can easily become aware compared to senior citizens. This lack of information has made senior citizens more fatalist and 
anxious at the same time. Almost $90.48 \%$ of senior citizens feel that they are suffering from anxiety. To this feeling of anxiety they adopt fatalism as one of their coping mechanisms.

On the other hand, people from the lowest range of income are more fatalist because if they follow the lockdown and health restriction rules, it would have an adverse impact on their livelihood and sources of income. In that sense, fatalism gives them the rationale of ignoring the rules and danger of COVID-19, and thus keeping their ways of income stable. Like senior citizens, people from the lowest income range too have less access to the information related to COVID-19 pandemic. Digital divide has been played a vital role in this context as the access of modern communication technology for getting information is directly associate with financial capacity and people from the lower income group are underprivileged in this context.

On the other hand, youths and people from the highest income range are comparatively less fatalist. In this case, one of the interviewees, who is a senior journalist who has observed this pattern, says that people are certainly becoming more reliant on fate. The number of people turning to faith while giving up their atheist or agnostic values isn't visibly high, but the number of believers practicing religion is certainly on the increase (M. Habib, personal communication, August 21, 2020). One important finding of the study shows that the level of uncertainty goes down with time when more people get to know about the virus. In the case of Bangladesh, it can be seen that every sector is now going normal except for educational institutions. On the other hand, youths are suffering more from uncertainty compared to the other two age groups. This is because they are having doubts about their education and career. In the same way, people from the lowest income range are facing more uncertainty. This is because they do not have any stable income source in this pandemic.

The survey results are compatible with the existing literature. Ruiu (2013) has connected religion more with fatalism. We can see that senior citizens who appeared as more fatalists, also think religious belief is more capable of combating the COVID-19, compared to the other age groups. Similarly, most of the senior citizens also think religious factors are more responsible for the widespread transmission of COVID-19. On the other hand, Durkheim (1897) argues that fatalism may stem from structural conditions such as inequality or extreme control overregulation. This can provide an explanation for why people from the lowest income range are more fatalist. This is because these people suffer from more structural inequalities in society. Hayes and Clerk (2020) mention that fatalistic beliefs make people pay less heed to social distancing and other mitigation efforts. But this study does not find similar conclusive information. Rather senior citizens and people from the lowest income range who are more fatalists, also believe that lockdown and social distancing measures can contribute to combating COVID-19. Hayes and Clerk (2020) further mention that fatalism towards the COVID-19 pandemic has a strong relation with emotional distress. This can explain why senior citizens feel more anxiety as their underlying health conditions and the weakness of putting in more effort make them more depressed and anxious.

\section{CONCLUSION AND SUGGESTION}

It is evident from the above discussion that, majority of the population in Bangladesh does not follow a fatalistic mindset. However, age and socio-economic structure have a significant impact on this pattern. The study shows that senior citizens and people from the lowest income range are comparatively more fatalist. On the other hand, senior citizens who are the most fatalists are also the people who suffer the most from anxiety. The reason behind this specific nature is because fatalistic views are positively related to mental stress. Even after being proved 
as fatalists, people from the lowest income range are suffering more from uncertainty. This can be ascribed to inequality in society that makes people more fatalists. low income and living below the poverty line lead to inequality or injustice. This makes people of these catagories fatalists. More specifically, the absence of a stable income source is contributing more to their uncertainty. In the study, most of the respondents believe that COVID-19 is a God-inflicted disease but it is not viewed as a punishment. However, most senior citizens regard the virus as a punishment from God. The study further shows that most people believe lockdown and social distancing can combat COVID-19. It is indicated that the people of Bangladesh are less fatalistic. Nonetheless, COVID-19 does have an impact on this mindset, making people more dependent on fate than ever before.

The findings of this study help us to understand the perception of our population more comprehensively and allow us to focus on how we can make people more aware of the factors that need critical intervention. The study findings further suggest that at times of disasters and pandemics, policymakers should take special initiatives for senior citizens and people with low income. These initiatives will make sure that they suffer less from anxiety and uncertainty during situations like this and become more cautious. This paper explores how the belief system of people is influenced by their socio-economic condition and how it affects their behavior in terms of combating pandemics. It also emphasizes that during disasters and pandemics, policymakers should take special initiatives for senior citizens and people with low income.

Due to the pandemic situation, some part of the data collection process was conducted through online survey. This has limited the depth of the data used in this study. Moreover, this study could have incorporated more respondents and a bigger timeline. That did not happen because of limited time and budget.

\section{Acknowledgments}

The authors wish to acknowledge with thanks the contribution of Rifat-E-Rabbi Alex, Khandaker Imtiaz Ahmed and Israt Jahan Disha during the data collection process.

\section{Conflict of Interest}

The authors declare no conflict of interest.

\section{Funding}

All the associated financial burden for conducting the study is the responsibility of the authors.

\section{REFERENCES}

Anwar, S., Nasrullah, M., \& Hosen, M. J. (2020, April 30). COVID-19 and Bangladesh: Challenges and How to Address Them. (Z. Kozlakidis, Ed.) Frontiers in Public Health, 8. https://doi.org/10.3389/fpubh.2020.00154

Acevedo, G., A. (2008). Islamic Fatalism and the Clash of Civilizations: An Appraisal of a Contentious and Dubious Theory, Social Forces, 86(4), 1711-1752.

https://doi.org/10.1353/sof.0.0033

Akesson, J., Hayes, S. A., Hahn, R., Metcalfe, R. D. \& Rasooly, I. (2020). Fatalism, Beliefs, and Behaviors During the COVID-19 Pandemic. National Bureau of Economic Research. http://www.nber.org/papers/w27245

BRAC, (2020). A rapid assessment: Impact of COVID-19 on Education in Bangladesh. . 
Available at: http://www.brac.net/program/wp-content/uploads/2020/07/Rapidassessment-impact-of-COVID-19-education-in-Bangladesh.pdf

Durkheim, E. (1951), Suicide, translated by John A. Spaulding and George Simpson, Glencoe, Ill.: Free Press.

Hayes, J., \& Clerk, L. (2021). Fatalism in the Early Days of the COVID-19 Pandemic: Implications for Mitigation and Mental Health. Frontiers In Psychology, 12. https://www.doi.org/10.3389/fpsyg.2021.560092

Jeronimus, B. F. (2020). Personality and Coronavirus 2019 Pandemic. University of Groningen Press, https://www.doi.org/10.21827/5ed9ebc01d65f

Kelly, A. H., Keck, F. \& Lynteris, C. (2019). The Anthropology of Epidemics. Routledge, New York, NY 10017.

Perilla, J., L., Norris, F., H \& Lavizzo, E., A. (2002), Ethnicity, Culture, and Disaster Response: identifying and explaining ethnic differences in PTSD six months after hurricane, Journal of Social and Clinical Psychology, 21, (1), 2002, 20-45.

https://www.doi.org/10.1521/jscp.21.1.20.22404

Qiu, W., Rutherford, S., Mao, A., \& Chu, C. (2017). The Pandemic and its Impacts. Health, Culture And Society, 9, 1-11. https://www.doi.org/10.5195/hcs.2017.221

Ramondt, S., \& Ramírez, A. (2017). Fatalism and exposure to health information from the media: examining the evidence for causal influence. Annals of The International Communication Association, 41(3-4), 298-320.

https://doi.org/10.1080/23808985.2017.1387502

Razzell, P. (1977). The Protestant Ethic and the Spirit of Capitalism: A Natural Scientific Critique. The British Journal of Sociology, 28(1), 17-37. https://doi.org/10.2307/589706

Ruiu, G. (2013). The Origin of Fatalistic Tendencies: an Empirical Investigation. ECONOMICS \& SOCIOLOGY, 6(2), 103-125. https://doi.org/10.14254/2071-789x.2013/6-2/10

Siddiquee, M. S. H., and Faruk, A. (2020) COVID-19's Impact on Bangladesh Economy. Macroeconomics Series 01. Available at: https://bigd.bracu.ac.bd/publications/covid19s-impact-on-bangladesh-economy/

Straughan, P., T. \& Seow, A. (1998), Fatalism Reconceptualized: A Concept to Predict Health Screening Behavior, Journal of Gender, Culture, and Health, 3(2), pp. 85-100.

Weber, M. (1930). The Protestant Ethic and the spirit of capitalism. Georg Allen \& Unwin. 